\title{
Alteration of Antioxidant Activity and Total Phenolic Content during the Eight-Week Fermentation of Apple Cider Vinegar
}

\author{
Havva Nilgün BUDAK ${ }^{1}$
}

${ }^{1}$ Department of Food Processing, Egirdir Vocational School, Isparta University of Applied Science, 32200, Isparta, Turkey

\author{
Article History \\ Received 26 October 2020 \\ Accepted 15 February 2021 \\ First Online 25 February 2021
}

\section{Corresponding Author}

E-mail: nilgunbudak@isparta.edu.tr

\section{Keywords}

Apple cider vinegar

Chlorogenic acid

ORAC

TEAC

Weekly antioxidant activity changes

\begin{abstract}
Apple is one of the delicious fruit consumed by people. Apple cider vinegar was made through the traditional method and the changes occurred during the 8 week fermentation period were determined in this research. Total titratable acidity, $\mathrm{pH}$, total soluble solids ( ${ }^{\circ} \mathrm{brix}$ ), total phenolic contents, Oxygen Radical Absorbance Capacity (ORAC) and Trolox Equivalent Antioxidant Capacity (TEAC) assays, phenolic contents were determined. Total phenolic substance, ORAC and TEAC values increased significantly weekly and reached the highest level in the $3^{\text {rd }}$ week. Total phenolic substance, ORAC and TEAC values of $3^{\text {rd }}$ week apple vinegar were determined as $1110.63 \mathrm{mg} \mathrm{GAE} \mathrm{L}^{-1}, 10.92 \mathrm{mM}$ and $21.11 \mu \mathrm{mol} \mathrm{TE} \mathrm{mL}^{-1}$, respectively. Apple vinegar samples had gallic acid, catechin, epicatechin, chlorogenic acid, and $\mathrm{p}$-coumaric acid. The major phenolic substances in apple vinegar were gallic acid and chlorogenic acid. While gallic acid value of $3^{\text {rd }}$ and $4^{\text {th }}$ week apple vinegar were detected 11.91 and $23.69 \mathrm{mg} \mathrm{L}^{-1}$, respectively; chlorogenic acid value of $4^{\text {th }}$ and $5^{\text {th }}$ week apple vinegar were found 46.36 and $49.71 \mathrm{mg} \mathrm{L}^{-1}$. Antioxidant activity and phenolic substances values were not significant reduction during the acetic acid fermentation. In this study, the formation process of the functional and sensory properties of apple cider vinegar due to the change in the weekly antioxidant and bioactive component content of apple cider vinegar was emphasized.
\end{abstract}

\section{Introduction}

Apple is a fruit commonly consumed by humans. In addition to this consumption as fruit, apple can also be turned into different products (such as jam, puree, apple wine, vinegar). Polyphenolic ingredients in apple composition positively affect human health (Boyer, 2004; Francini and Sebastiani, 2013). There are over 8000 polyphenols which has known as antioxidants in nature. Polyphenols protect our body against damage caused by free radicals (Ganesan and Xu, 2017). Briefly, polyphenolics have been asserted to effective on human health (preventing chronic disease such as cancer, heart attack, hypertension, and diabetes) (Halliwell, 2007). Each of polyphenols may have private health impact (Manach et al., 2004). Apple vinegar comprises of polyphenols such as chlorogenic acid, gallic acid, catechin, epicatechin (Budak et al., 2011). Chlorogenic acid which is abundant in apples has been also indicated to inhibit DNA damage in vitro (Kasai et al., 2000) and displayed a preservative effect against cardiovascular diseases (Laranjinha et al., 1994). Budak et al. (2011) indicated that total phenolic content, chlorogenic acid, antioxidant (ORAC and TEAC) activities values of apple vinegar were the higher determined by surface (traditional) methods with maceration than submersion (industrial) methods with and without maceration. Besides, 
different phenolic contents (gallic acid, epicatechin, chlorogenic acid etc.) were detected in apple cider vinegars while chlorogenic acid had been identified as the predominant phenolic content in apple vinegar samples (Budak et al., 2011).

Apple cider vinegar is one of the most commonly known in vinegar types. Although the first known usage of vinegar dates back to a century ago (Johnston and Gaas, 2006; Tan, 2005), vinegar has been widely used in food industry in recent 20 years. There are different kinds of vinegar which are balsamic, cane, champagne, cider, vinegar, distilled, malt, rice wine, sherry, wine (Tan, 2005). Vinegar has a double fermentation processes using different raw materials. These stages are ethanol and acetic acid fermentations. In addition, vinegar is produced by different production methods. While the fermentation in the traditional method (a surface-slow method) occurs on the surface of a barrel following wine or cider; the fermentation in the industrial method (a submersion (quick) method); consists a fermentator in the continuous oxygenation, optimum temperature (Tan, 2005). Acetic acid bacteria are responsible for vinegar production (Ley et al., 1984). Vinegar should contain at least $4 \%$ acetic acid (TSE, 2016). The final quality of vinegars depend on the selection of appropriate starter culture, starting material, the production method, maturation and aging (Mas et al., 2014).

The aromatic compounds, polyphenolic compounds and antioxidant activity of vinegar change during the vinegar formation process. Budak et al. (2014) reported that vinegar has high antioxidant and antibacterial activity. Vinegar has been found to be effective in cholesterol metabolism and reducing liver fat. Du et al. (2019) determined that apple pulp obtained by cold pressing technology has significant high antioxidant capacity and bioactive compounds. They reported that vinegar which has high bioactive content can be produced from this pulp. Chlorogenic acid, caffeic acid, phlorizin, gallic acid, coumaric acid, ferulic acid and vanilla acid detected 6.56, 3.03, 1.76, 0.35, $0.33,0.24,0.06 \mathrm{mg} \mathrm{L}^{-1}$ in apple cider vinegar, respectively (Du et al., 2019). In other study, antioxidant analyzes were performed on the filtered (FAV), clarified (CAV) and packaged (PAV) of apple vinegar samples in the industrial vinegar process (Bakir et al., 2016). They determined that total phenolic content of CAV, FAV, PAV had 383, 357, $459 \mathrm{mg}^{\mathrm{GAE}} 100 \mathrm{mg}^{-1}$; TEAC value of CAV, FAV,

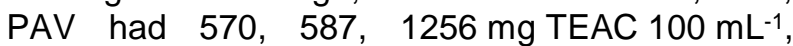
respectively. It was observed that apple vinegar contain gallic acid, syringic acid, caffeic acid, $p$ hydroxybenzoic acid, catechin, and p-coumaric acid (Bakir et al., 2016).

So far, we have not found any previously published studies on determining the weekly antioxidant activity and phenolic components of the apple cider vinegar process. In this study, weekly changes of antioxidant properties and bioactive substances were determined during the apple cider vinegar process.

\section{Material and Methods}

Apples were harvested in Isparta (in two different regions). Food Engineering laboratory in Suleyman Demirel University was used to convert apples into vinegar and analyzes. Figure 1 shows traditional vinegar production methods. During apple cider and vinegar formation, samples were taken weekly. Apple juice sample was coded as V0. Samples taken during ethanol fermentation and acetic acid fermentation at $1,2,3,4,5,6,7$, and 8 weekly samples were coded as V1, V2, V3, V4, V5, V6, V7, and $\mathrm{V} 8$, respectively.

Total titratable acidity, $\mathrm{pH}$, total soluble solid ( $\left.{ }^{\circ} \mathrm{Brix}\right)$ of samples were detected according to AOAC (1992) methods. Total titratable acidity of juice, cider, vinegar was expressed as malic acid, lactic acid, acetic acid, respectively. $\mathrm{pH}$ meter (WTW, Inolab, USA) and Abbe refractometer (Bellingham Stanley Limit 60/70 Refractometer, England) were used in $\mathrm{pH}$ and total soluble solids measurements. Ethanol content of apple cider samples were detected with alcoholometer (Dujardin-Salleron, France).

Folin-Ciocalteu method was used for determination of total phenolic content and "mg GAE L-1" was used to express the values (Singleton et al., 1999).

The hydrophilic ORAC-Fluorescein method were used to detect the Oxygen Radical Absorbance Capacity (ORAC) (Davalos et al., 2005). ORAC values were kinetically calculated in BioTek Instruments (Winooski, Vermont, USA) and indicated as " $\mu \mathrm{mol}$ TE $\mathrm{mL}^{-1 "}$.

Total antioxidant capacity was made according to the method determined by Seeram et al. (2005). "mM TE" was used in order to express the TEAC assay.

The identification and quantification of phenolic compounds in samples carried out a highperformance liquid chromatography (Shimadzu, Kyoto, Japan) according to Caponio et al. (1999). The system includes a pump (LC-10ADvp), autosampler (SIL-10AD vp), a DAD detector ( $\lambda \max =278)$, system controller (an SCL-10Avp), degasser (DGU-14A), column oven (a CTO-10Avp), column (Inertsil ODS-3V C18) (GL Sciences Inc.). Standart chromatogram was shown Figure 2. Phenolic compounds were stated as " $\mathrm{mg} \mathrm{L}^{-1 "}$.

Yeasts were grown on Potato Dextrose Agar (PDA, Merck, Darmstadt, Germany) at $25^{\circ} \mathrm{C}$ for 5 days. It was added lactic acid (0.14\%) (Özdemir et al., 2015). Acetic acid bacteria were counted on Glucose Yeast Extract Agar (GYC, Merck, Darmstadt, Germany) with cycloheximide (100 $\mathrm{ppm}$ ) at $30^{\circ} \mathrm{C}$ for 5-7 days (Yetiman, 2012).

Vinegar productions was done in duplicate and two in parallel and all experiments were repeated 


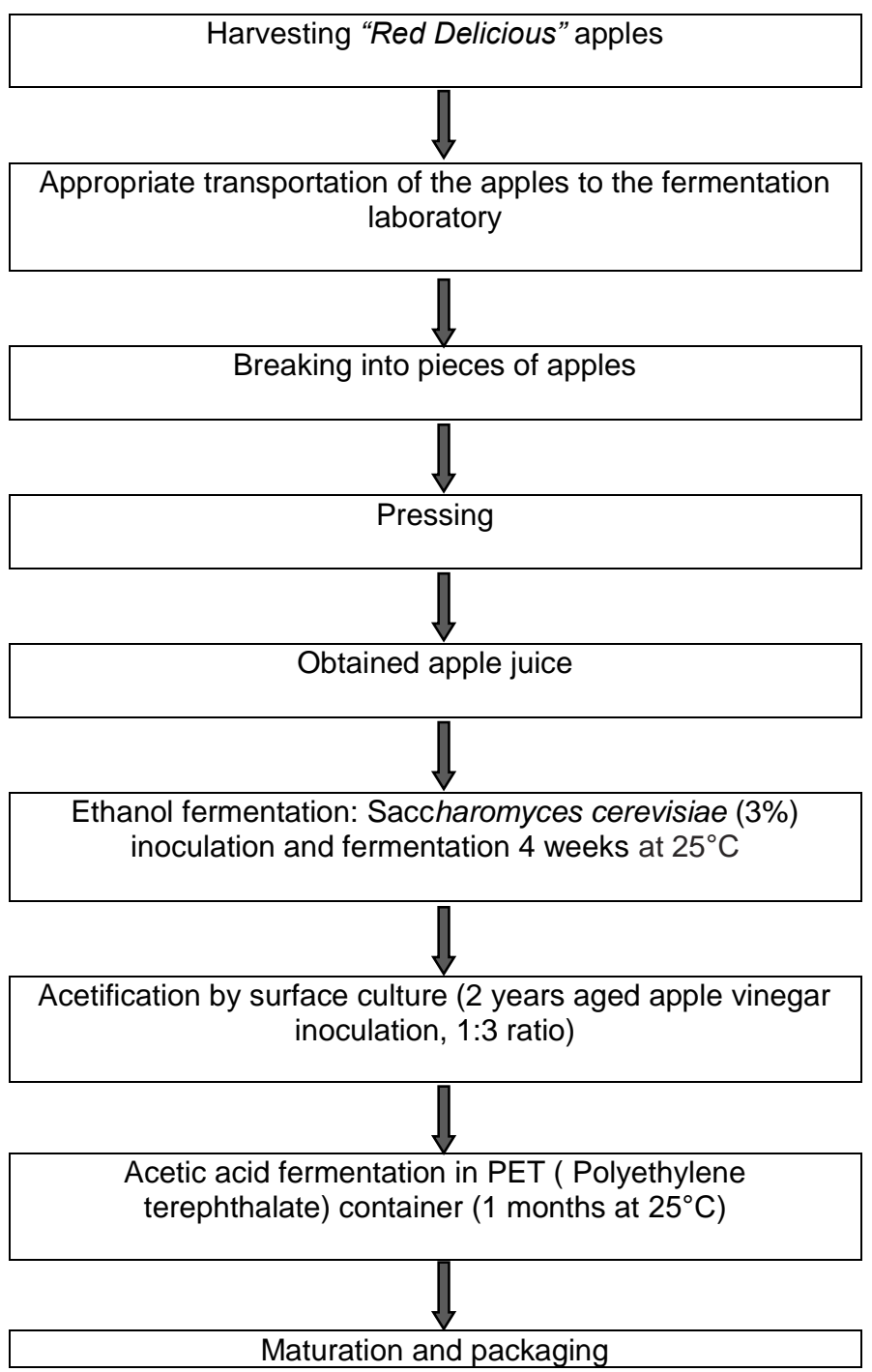

Figure 1. Flow chart of apple cider vinegar

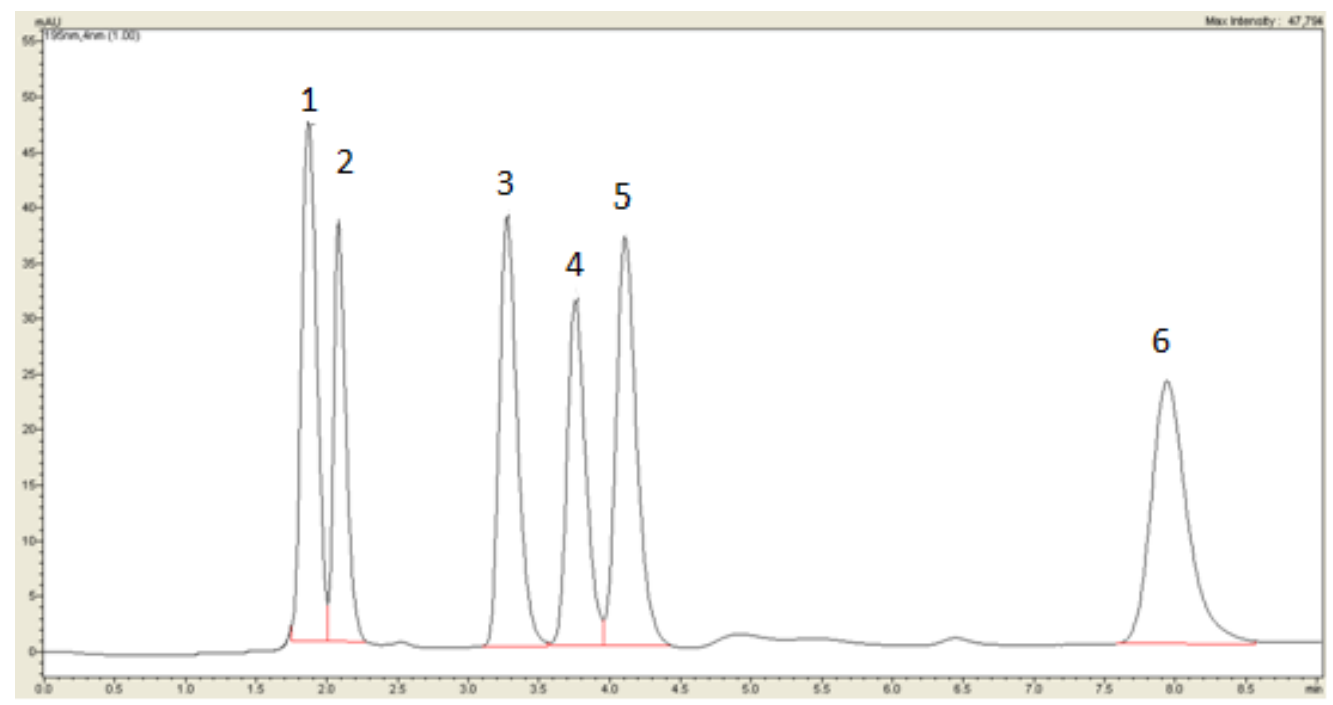

Figure 2. A chromatogram of standard (1: gallic acid, 2: chlorogenic acid, 3: catechin, 4: caffeic acid, 5: epicatechin, and 6: rutin) 
three times. A one-way analysis of variance (ANOVA) was applied using SPSS 18.0 (SPSS, 2010). The mean \pm SEM was used to express the results.

\section{Results and Discussion}

$\mathrm{pH}$ values, total acidity (\%) and total soluble solids ( ${ }^{\circ}$ Brix) of weekly samples were shown in Table 1. While $\mathrm{pH}$ had steadily decreased, total acidity had gradually increased during fermentation. $\mathrm{pH}$, total acidity, brix values have significantly changed in the first week. Chemical transformation in yeast fermentation has also significantly affected these values $(P<0.05) . \mathrm{pH}$ changes in the $1^{\text {st }}, 2^{\text {nd }}$, $3^{\text {rd }}$ in weeks were not found to be statistically significant $(P>0.05)$. Besides, after the $3^{\text {rd }}$ week, the $\mathrm{pH}$ tended to decrease significantly $(\mathrm{P}<0.05)$ and the $\mathrm{pH}$ was observed at close values until the $8^{\text {th }}$ week $(P>0.05)$. In the $8^{\text {th }}$ week, the $\mathrm{pH}$ value showed a decrease and the $\mathrm{pH}$ value of $\mathrm{V} 8$ had 3.38 and it was observed that the vinegar formation was completed. Total acidity of $2^{\text {nd }}, 3^{\text {rd }}, 4^{\text {th }}$ weeks had increased $(P>0.05)$ but total acidity of $7^{\text {th }}$ and $8^{\text {th }}$ weeks had significantly increased $(P<0.05)$. While the total acidity values of the wine and the juice were close to each other, the value of the vinegar was higher than them $(P<0.05)$. It was considered that the increase of the total acidity value in these stage of fermentation, might be caused by the production of mainly acetic acid and other organic acids, also the stability of the $\mathrm{pH}$ value might be caused by a weak acid property of the organic acid. Because, while the $\mathrm{pH}$ value was expressed as a negative logarithm of the concentration of dissociated hydrogenions, titratable acidity deals with measurement of the total acid concentration contained within a food, regardless of the effectiveness of the acid, that is, whether it is weak or strong. While the $\mathrm{pH}$ values of the wine and the juice were close to each other, the value of the vinegar was lower than them $(P<0.05)$. This situation has also observed in vinegar productions using different fruits (Sadler and Murphy, 2010). Budak (2010) reported that total acidity of apple vinegar samples was $57.2 \mathrm{~g} \mathrm{~L}^{-1}$. Moreover, total soluble solid of apple juice was $14\left({ }^{\circ} \mathrm{Brix}\right)$, this value decreased step by step in the ethanol fermentation $(P<0.05)$. Especially, there was a significant decrease in brix value in the first week $(P<0.05)$. Because, sugar has turned into ethanol by alcohol fermentation (Treck and Teuber, 2002). Total soluble solid of $\mathrm{V} 8$ had shown $2.15^{\circ} \mathrm{Brix}$ in the end of fermentation. Alcohol value reached its highest value at $3^{\text {rd }}$ week, and this value remained the same in the $4^{\text {th }}$ week. Acetic acid fermentation was started in the $4^{\text {th }}$ week. That's why alcohol value decreased with the initiation of acetic acid fermentation $(P<0.05)$. Since, acetic acid bacteria operates under oxygen, alcohol, suitable temperature conditions for acetic acid fermentation (Guillamon and Mas, 2011). Yeast counted during ethanol fermentation. Acetic acid bacteria counted during acetic acid fermentation (Table 1). In the post-inoculation yeast count was the highest observed at the end of the $1^{\text {st }}$ week. Yeast count and decreased in sugar consumption is balanced with each other. The yeast value entered the stationary phase in the $3^{\text {rd }}$ and $4^{\text {th }}$ weeks. Finally, yeast entered the death phase at $5^{\text {th }}$ week and counting could not be made. Acetic acid bacteria count was determined between 4.55 and $5.80 \log$ kob $\mathrm{mL}^{-1}$.

Total phenolic contents (TPC) of samples were presented in Figure 3. Total phenolic substance value increased significantly weekly $(\mathrm{P}<0.05)$ and reached the highest level in the $3^{\text {rd }}$ week. Total phenolic substance was $1110.63 \mathrm{mg} \mathrm{GAE} \mathrm{L}^{-1}$ in V3

Table 1. Chemical properties and phenolic compounds of samples (8 weeks)

\begin{tabular}{|c|c|c|c|c|c|c|c|c|c|c|c|}
\hline $\mathrm{S}$ & $\mathrm{pH}$ & TA (\%) & TSS & $A$ & $\mathrm{Y}$ & $A A B$ & $\mathrm{GA}$ & $\mathrm{CA}$ & C & $E$ & $p-C A$ \\
\hline \multirow{2}{*}{ V0 } & 4.38 & 1.64 & 14.00 & & 5.56 & & 7.94 & 12.16 & 1.24 & 0.41 & 0.06 \\
\hline & $\pm 0.04^{a}$ & $\pm 0.09^{c}$ & $\pm 0.46^{\mathrm{a}}$ & & $\pm 0.08^{b}$ & & $\pm 1.17^{\mathrm{b}}$ & $\pm 1.41^{\mathrm{b}}$ & $\pm 0.33^{a}$ & $\pm 0.05^{b}$ & $\pm 0.01^{b}$ \\
\hline \multirow{2}{*}{ V1 } & 3.91 & 2.32 & 6.25 & 7.30 & 7.14 & & 9.33 & 33.52 & 1.69 & 1.28 & 0.07 \\
\hline & $\pm 0.08^{b}$ & $\pm 0.01^{b c}$ & $\pm 0.89^{b}$ & $\pm 0.24^{b}$ & $\pm 0.09^{a}$ & & $\pm 1.02^{\mathrm{b}}$ & $\pm 0.51^{\mathrm{b}}$ & $\pm 0.11^{\mathrm{a}}$ & $\pm 0.10^{\mathrm{b}}$ & $\pm 0.01^{b}$ \\
\hline \multirow{2}{*}{ V2 } & 3.90 & 2.31 & 4.75 & 8.35 & 5.81 & & 10.36 & 35.38 & 2.05 & 3.24 & 0.12 \\
\hline & $\pm 0.07^{b}$ & $\pm 0.02^{\mathrm{bc}}$ & $\pm 0.26^{b c}$ & $\pm 0.14^{a}$ & $\pm 0.10^{\mathrm{b}}$ & & $\pm 0.76^{b}$ & $\pm 0.91^{\mathrm{ab}}$ & $\pm 0.16^{\mathrm{a}}$ & $\pm 0.08^{a}$ & $\pm 0.01^{\mathrm{ab}}$ \\
\hline \multirow{2}{*}{ V3 } & 3.67 & 2.33 & 3.45 & 8.59 & 4.38 & & 11.91 & 41.05 & 2.09 & 3.65 & 0.16 \\
\hline & $\pm 0.09^{b c}$ & $\pm 0.01^{b c}$ & $\pm 0.20^{\mathrm{cd}}$ & $\pm 0.15^{a}$ & $\pm 0.20^{b}$ & & $\pm 2.20^{\mathrm{b}}$ & $\pm 1.05^{a}$ & $\pm 0.49^{a}$ & $\pm 0.20^{a}$ & $\pm 0.04^{\mathrm{ab}}$ \\
\hline \multirow{2}{*}{ V4 } & 3.53 & 2.23 & 3.60 & 8.55 & 4.18 & 5.24 & 23.69 & 46.36 & 1.92 & 3.55 & 0.19 \\
\hline & $\pm 0.05^{\mathrm{cd}}$ & $\pm 0.03^{b c}$ & $\pm 0.12^{\mathrm{cd}}$ & $\pm 0.15^{a}$ & $\pm 0.11^{b}$ & $\pm 0.02^{\mathrm{a}}$ & $\pm 1.35^{\mathrm{a}}$ & $\pm 2.78^{a}$ & $\pm 0.15^{\mathrm{a}}$ & $\pm 0.18^{a}$ & $\pm 0.01^{a}$ \\
\hline \multirow{2}{*}{ V5 } & 3.43 & 3.47 & 3.25 & 3.45 & & 5.56 & 25.58 & 49.71 & 1.75 & 2.67 & 0.17 \\
\hline & $\pm 0.04^{\mathrm{cd}}$ & $\pm 0.11^{\mathrm{b}}$ & $\pm 0.43^{\mathrm{cd}}$ & $\pm 0.16^{c}$ & & $\pm 0.09^{a}$ & $\pm 1.48^{\mathrm{a}}$ & $\pm 2.93^{\mathrm{a}}$ & $\pm 0.42^{\mathrm{a}}$ & $\pm 0.14^{a}$ & $\pm 0.03^{a b}$ \\
\hline \multirow{2}{*}{ V6 } & 3.47 & 3.87 & 2.95 & & & 5.80 & 27.22 & 45.64 & 1.50 & 2.79 & 0.13 \\
\hline & $\pm 0.05^{\mathrm{cd}}$ & $\pm 0.03^{b}$ & $\pm 0.32^{d}$ & & & $\pm 0.03^{a}$ & $\pm 0.99^{a}$ & $\pm 1.56^{\mathrm{a}}$ & $\pm 0.48^{a}$ & $\pm 0.31^{\mathrm{a}}$ & $\pm 0.02^{a b}$ \\
\hline \multirow{2}{*}{ V7 } & 3.51 & 4.54 & 2.35 & & & 5.10 & 24.83 & 43.45 & 1.59 & 2.80 & 0.11 \\
\hline & $\pm 0.04^{\mathrm{cd}}$ & $\pm 0.07^{a}$ & $\pm 0.08^{d}$ & & & $\pm 0.05^{\mathrm{a}}$ & $\pm 2.93^{\mathrm{a}}$ & $\pm 2.01^{\mathrm{a}}$ & $\pm 0.42^{\mathrm{a}}$ & $\pm 0.27^{\mathrm{a}}$ & $\pm 0.04^{\mathrm{ab}}$ \\
\hline \multirow{2}{*}{ V8 } & 3.38 & 5.19 & 2.15 & & & 4.55 & 25.68 & 45.07 & 1.54 & 2.66 & 0.08 \\
\hline & $\pm 0.05^{d}$ & $\pm 0.09^{a}$ & $\pm 0.08^{d}$ & & & $\pm 0,03^{a}$ & $\pm 3.39^{a}$ & $\pm 2.48^{\mathrm{a}}$ & $\pm 0.47^{a}$ & $\pm 0.48^{a}$ & $\pm 0.01^{\mathrm{ab}}$ \\
\hline
\end{tabular}

S:Samples, TA: Total acidity (\%), TSS:Total soluble solids ( ${ }^{\circ}$ Brix), A: Alcohol, Y: Yeast (log kob mL $\left.{ }^{-1}\right)$, AAB: Acetic acid bacteria (log kob mL-1), GA: Gallic acid (mg L-1), CA:Chlorogenic acid $\left(\mathrm{mg} \mathrm{L}^{-1}\right)$, C: Catechin (mg L-1), E: Epicatechin $\left(\mathrm{mg} \mathrm{L}^{-1}\right), p-C A: p-C o u m a r i c$ acid $\left(\mathrm{mg} \mathrm{L}^{-1}\right)$

Data expressed as mean \pm standard error (SEM). a, b, c, d: There is a statistically significant difference between groups in the same column without common letters $(P<0.05)$. 


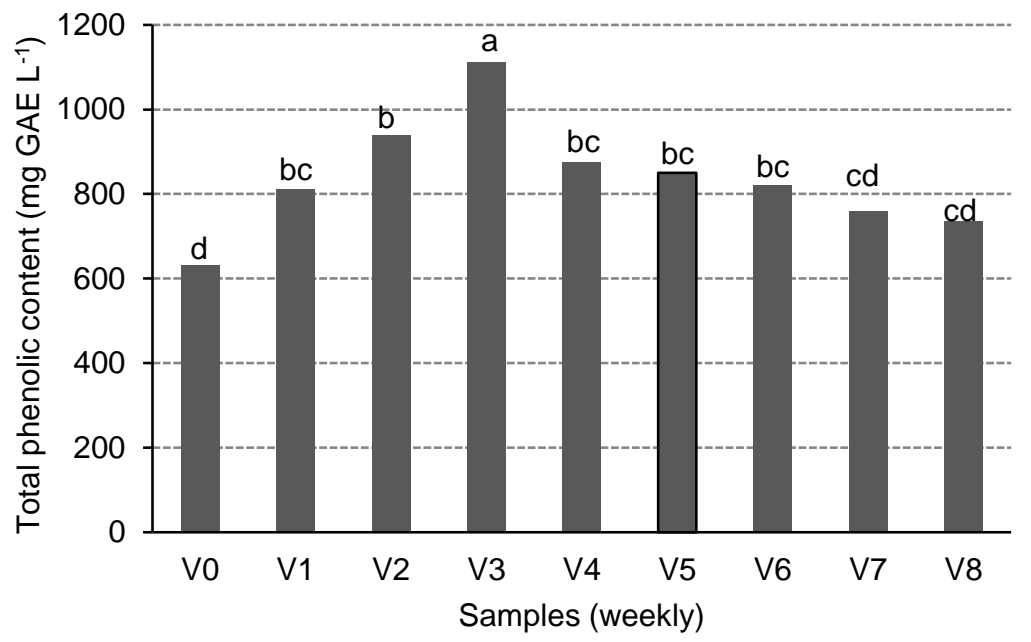

a

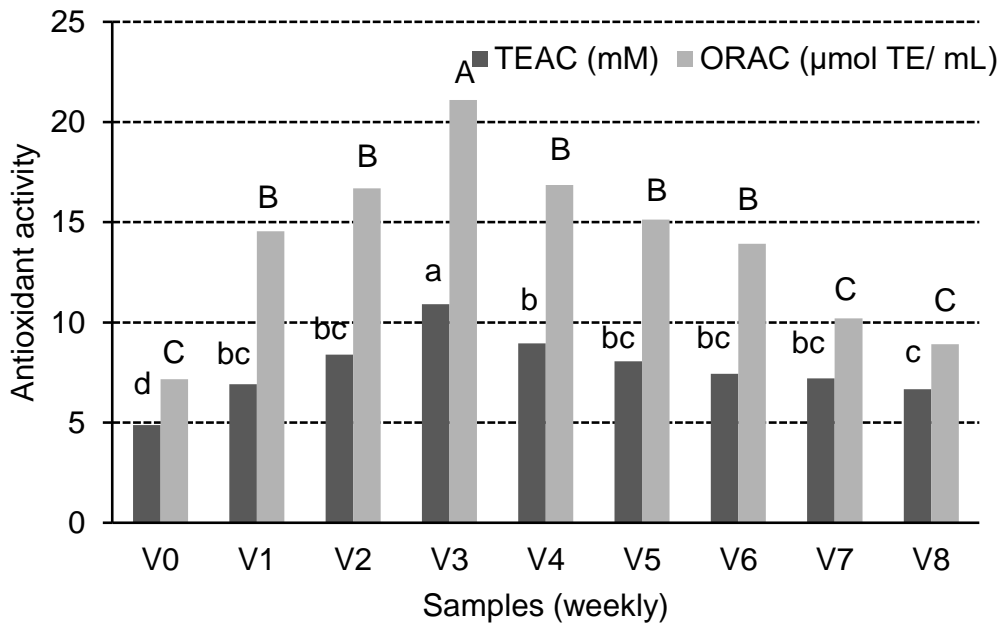

$b$

Figure 3. Total phenolic contents (a) and antioxidant activity (b) of samples (Data expressed as mean \pm standard error (SEM). $\mathrm{a}, \mathrm{b}, \mathrm{c}, \mathrm{d}$ : There is a statistically significant difference between samples without common letters $(P<0.05)$. Capital letters and lower case letters are evaluated among themselves $(P<0.05)$.

sample. TPC of the V4 sample decreased to $876.25 \mathrm{mg} \mathrm{GAE} \mathrm{L}^{-1}$ with the start of acetic acid fermentation $(P<0.05)$. After the $4^{\text {th }}$ week, TPC values started to decrease, but no significant decreases were observed $(P>0.05)$. TPC values of V5, V6, V7, and V8 had 850.15, 820.03, 758.56, $734.55 \mathrm{mg} \mathrm{GAE} \mathrm{L}^{-1}$, respectively. The weekly analyzed results show that the total phenolic matter values increased during ethanol fermentation $(P<0.05)$ and did not change throughout acetic acid fermentation $(P>0.05)$. This increase could be associated with the release of the phenolic acids bound to sugar or/and organic acid molecules in the juice in the alcohol fermentation (Crozier et al., 2009).

In the literature research conducted so far, although there is no weekly follow-up in apple vinegar process, total phenolic substance results in apple juice, wine and vinegar samples have been determined. It was indicated that the total phenolic content were 3392 (Rababah et al., 2005), 21103470 (Wu et al., 2004), 1100-3570 (Podsedek et al.,
2000; Liu et al., 2001), $977 \mathrm{mg} \mathrm{GAE} \mathrm{L-1}^{-1}$ (Wolfe et al., 2003) in apple juice samples; 730$1343 \mathrm{mg} \mathrm{GAE} \mathrm{L}^{-1}$ in apple cider produced with different techniques (Budak et al., 2015); 908, 568, $757,416 \mathrm{mg} \mathrm{GAE} \mathrm{L}^{-1}$ of apple vinegars produced with different techniques (Budak et al., 2011), 33$284 \mathrm{mg} \mathrm{GAE} \mathrm{L}^{-1}$ apple vinegars (Du et al., 2019), 357-459 mg GAE L-1 (Bakir et al., 2016), 43$495 \mathrm{mg} \mathrm{GAE} \mathrm{L}^{-1}$ in eleven apple vinegars purchased from local markets in China (Liu et al., 2019).

The differences in the total phenolic content of apple juice can vary according to apple varieties and growing conditions, and this change is reflected in the products produced from apple (apple wine, apple cider vinegar). TEAC (ABTS-) and ORAC values of apple samples were presented in Figure 3. ORAC and TEAC values were similar tendency in weekly measurements of apple samples. ORAC and TEAC values increased weekly until the $3^{\text {rd }}$ week $(\mathrm{P}<0.05)$. ORAC and TEAC values reached the highest antioxidant value in the $3^{\text {rd }}$ week. 
TEAC and ORAC value of V3 (apple cider) had $10.92 \mathrm{mM}$ and $21.11 \mu \mathrm{mol}$ TE $\mathrm{mL}^{-1}$, respectively. While the decrease in the ORAC value in acetic acid fermentation was significant $(P<0.05)$, the decrease in the TEAC value was not significant $(P>0.05)$. It has been stated that yeast use and fermentation conditions affect phenolic compounds during ethanol fermentation (Brandolini et al., 2007). Because, phenolic compounds related to sugar are released when yeast uses sugar, and antioxidant activity increases during fermentation (Crozier et al., 2009). Ubeda et al. (2011) reported that ORAC value of balsamic vinegar, apple vinegar, sherry vinegar, persimmon vinegar, red wine vinegar had 40049, 8986, 7879, 1857, and $1462 \mu \mathrm{mol}$ TE kg-1, respectively. Budak et al. (2011) determined that ORAC values between 3.00 and $5.89 \mu \mathrm{mol} \mathrm{mL}^{-1}$ in apple vinegar samples, while TEAC values between 5.4 and $13.5 \mathrm{mmol}^{-1}$. In our study, ORAC values of apple vinegar (V8) had $8.90 \mu \mathrm{mol}$ TE $\mathrm{mL}^{-1}$.

Gallic acid, catechin, epicatechin, chlorogenic acid, and p-coumaric acid were detected in all samples (Table 1). Contents of catechin, epicatechin and p-coumaric acid were lower than gallic acid and chlorogenic acid content in all samples. Gallic acid content of samples increased weekly until the $4^{\text {rd }}$ week $(P>0.05)$. Gallic acid value of $\mathrm{V} 3$ and $\mathrm{V} 4$ had 11.91 and $23.69 \mathrm{mg} \mathrm{L}^{-1}$, respectively $(P<0.05)$. This increases could be associated with the release of the phenolic acids bound to sugar or/and organic acid molecules in the juice, in the alcoholic mediums (Crozier et al., 2009). Differences in gallic acid value were not significant in acetic acid fermentation ( $P>0.05)$. Chlorogenic acid was the dominant phenolic substance in apple cider and apple cider vinegar samples; especially, V4 and V5 samples had the highest content of chlorogenic acid. Budak et al. (2011) reported that chlorogenic acid of apple cider vinegar sample had $18.67 \mathrm{mg} \mathrm{L}^{-1}$ and chlorogenic acid was the dominant phenolic substance in apple vinegar. Catechin, epicatechin, p-coumaric acid content of V8 had 1.54, 2.66 and $0.08 \mathrm{mg} \mathrm{L}^{-1}$, respectively. It has been shown that epicatechin significantly changed $2^{\text {nd }}$ week while coumaric acid significantly changed $4^{\text {th }}$ week $(P<0.05)$. The leading polyphenols in apple cider vinegar were chlorogenic acid, caffeic acid, phlorizin, vanilla acid, gallic acid, coumaric acid and ferulic acid (Du et al., 2019). Phenolic compounds in apples changes induced by apple cultivar, breeding approaches, fruit postharvest and transformation into juice. Total and individual polyphenols in apple cultivars and cultivation may have been shown to vary (Volz and McGhie, 2011). As a result of weekly analyzes, we was observed that gallic acid and chlorogenic acid content was the dominant phenolic component in apple cider vinegar.

\section{Conclusion}

This study is the first detailed report determining the weekly change in antioxidant properties and bioactive substances during fermentation of apple cider vinegar. These values reached the highest value as a result of ethanol fermentation and no significant change was observed during acetic acid fermentation. Significant biochemical changes were observed especially until the $4^{\text {th }}$ week of fermentation. As a result, it was observed that the antioxidant and phenolic component values increased with the release of phenolic compounds bound to sugar as a result of using the sugar in the fruit by yeast. It is important for human health to increase the usage area and consumability of apple cider vinegar and to benefit from its functional properties. In addition, being preferred for its sensory properties, apple wine and vinegar is one of the important functional products for health. Determining the weekly change of apple cider vinegar made from apple fruit in terms of antioxidant and phenolic components (especially gallic acid and chlorogenic acid) is important in terms of detecting the change in fermentation steps. This study will shed light on the emergence of new studies especially in fermentation stages.

\section{References}

AOAC, (1992). Association of Official Analytical Chemists. Official Methods of Analysis, 15th ed.; AOAC: Washington, DC.

Bakir, S., Toydemir G., Boyacioglu D., Beekwilder J., \& Capanoglu, E. (2016). Fruit antioxidants during vinegar processing: changes in content and in vitro bio-accessibility. International Journal of Molecular Sciences, 17:1-12.

Boyer, J., \& Liu, R.H. (2004). Apple phytochemicals and their health benefits. Journal of Nutrition, 12:3-5.

Brandolini, V., Fiore, C., Maietti, A., Tedeschi, P., \& Romano, P. (2007). Influence of Saccharomyces cerevisiae strains on wine total antioxidant capacity evaluated by photochemiluminescence. World Journal of Microbiology and Biotechnology, 23:581586.

Budak, H.N. (2010). A research on compositional and functional properties of vinegars produced from apple and grape. PhD Thesis, Suleyman Demirel University, Isparta, Turkey.

Budak, H.N., Kumbul-Doguç, D., Savaş, C.M., Seydim, A.C., Kök-Taş, T., Ciriş, I.M., \& Güzel-Seydim, Z.B. (2011). Effects of apple cider vinegars produced with different techniques on blood lipids in highcholesterol-fed rats. Journal of Agricultural and Food Chemistry, 59:6638-44.

Budak, H.N., Aykin, E., Seydim, A.C., Greene, A.K., \& Guzel-Seydim, Z.B. (2014). Functional properties of vinegar. Journal of Food Science, 79:757-764.

Budak, H.N., Özçelik, F., \& Guzel-Seydim, Z.B. (2015). Antioxidant activity and phenolic content of apple cider. Turkish Journal of Agriculture - Food Science and Technology 3:356-360.

Caponio, F., Alloggio, V., \& Gomes, T. (1999). Phenolic compounds of virgin olive oil: influence of paste preparation techniques. Food Chemistry, 63:203-209.

Crozier, A., Jaganath, I.B., \& Clifford, M.N. (2009). Dietary phenolics: chemistry, bioavailability and effects on 
health. Dietary phenolics: chemistry, bioavailability and effects on health. Natural Product Reports, 26: 1001-1043.

Davalos, A., Bartolome, B., \& Gomez-Cordoves, C. (2005). Antioxidant properties of commercial grape juices and vinegars. Food Chemistry, 93:325-330.

Du, G., Zhu, Y., Wang, X., Zhang, J., Tian, C., Liu, L., Meng, Y., \& Guo, Y. (2019). Phenolic composition of apple products and by-products based on cold pressing technology. Journal of Food Science and Technology, 56:1389-1397.

Francini, A., \& Sebastiani, L. (2013). Phenolic compounds in apple (Malus $\mathrm{x}$ domestica Borkh.):Compounds characterization and stability during postharvest and after processing. Antioxidants, 2:181-193.

Ganesan, K., \& Xu, B. (2017). A critical review on polyphenols and health benefits of black soybeans. Nutrients. 9: 455.

Guillamon, J.M. \& Mas, A. (2011). Chapter 9; Acetic acid bacteria in Molecular Wine Microbiology, Pages 227255, Academic Press, ISBN: 978-0-12-375021-1.

Halliwell, B. (2007). Dietary polyphenols: good, bad, or indifferent for your health? Cardiovascular Research, 73: 341-347.

Johnston, C.S., \& Gaas, C.A. (2006). Vinegar: medicinal uses and antiglycemic effect. Medscape General Medicine, 8(2):61.

Kasai, H., Fukada, S., Yamaizumi, Z., Sugie, S., \& Mori, $\mathrm{H}$. (2000). Action of chlorogenic acid in vegetables and fruits as an inhibitor of 8-hydroxydeoxyguanosine formation in vitro and in a rat carcinogenesis model. Food Chemical Toxicology, 38:467-471.

Laranjinha, J.A., Almeida, L.M., \& Madeira, V.M. (1994). Reactivity of dietary phenolic acids with peroxyl radicals: antioxidant activity upon low density lipoprotein peroxidation. Biochemical Pharmacology, 48:487-494.

Ley, J., Gossele, F. \& Swings, J. (1984). Genus I Acetobacter, in Bergey's Manual of Systematic Bacteriology, vol. 1, pp. 268-274, Williams \& Wilkens, Baltimore, Md, USA

Liu, R.H., Eberhardt, M.V., \& Lee, C.Y. (2001). Antioxidant and antiproliferative activites of selected New York apple cultivars. New York Fruit Quarterly, 9:15-17.

Liu, Q., Tang, GY, Zhao, C.N., Gan, R.Y., \& Li, H.B., (2019). Antioxidant activities, phenolic profiles, and organic acid contents of fruit vinegars. Antioxidants, 8(4):78.

Manach, C., Scalbert, A., Morand, C., Rémésy, C., \& Jimenez, L. (2004). Polyphenols - Food sources and bioavailability. The American Journal of Clinical Nutrition 79: 727-747.

Mas, A., Torija, M.J., García-Parrilla, M.C., \& Troncoso, A.M. (2014). Acetic Acid Bacteria and the Production and Quality of Wine Vinegar. The Scientific World Journal, 394671:1-6.

Özdemir, N., Kök Taş, T., \& Güzel-Seydim, Z.B. (2015). Effect of Gluconacetobacter spp. on kefir grains and kefir quality. Food Science and Biotechnology, 24:99106.
Podsedek, A., Wilska-Jeska, J., Anders, B. \& Markowski, J. (2000). Compositional characterisation of some apple varieties. European Food Research and Technology, 210:268-272.

Rababah, T.M., Ereifej, K.I., \& Howard, L. (2005). Effect of ascorbic acid and dehydration on concentrations of total phenolics, antioxidant capacity, anthocyanins, and color in fruits. Journal of Agricultural and Food Chemistry, 53:4444-4447.

Sadler, G.D., \& Murphy, P.A. (2010).pH and titratable acidity. Nielsen, S. S. (Ed.). Food analysis. (pp. 219238). Boston: Springer.

Seeram, N., Adams, L., \& Henning, S. (2005). In vitro antiproliferative apoptotic and antioxidant activities of punicalagins, ellagic acid and a total pomegranate tannin extract are enhanced in combination with other polyphenols as found in pomegranate juice. Journal of Nutritional Biochemistry, 16:360-367.

Singleton, V.L., Orthofer, R., \& Lamuela-Raventos, R.M. (1999). Analysis of total phenols and other oxidation substrates and antioxidants by means of FolinCiocalteau reagent. Methods Enzymology, 299:152178.

SPSS, (2010). Brief Guide. SPSS Inc., Version 13.0, Chicago, USA.

Tan, S.C. (2005). Vinegar fermentation. Master of Science thesis, Louisiana State University, Department of Food Science, Baton Rouge. 101 p.

Treck, J., \& Teuber, M. (2002) Genetic and Restriction Analysis of the 16S-23S rDNA Internal Transcriped Spacer Regions of the Acetic acid bacteria. FEMS Microbiology Letters, 208:69-75.

TSE, (2016). Vinegar - Product-recipes, features and markings obtained from liquids of agricultural origin. TS 1880 EN 13188 D1, Turkish Standardization Institute, Ankara, Turkey.

Ubeda, C., Hidalgo, C., Torija, M.J., Mas, A., Troncoso, A.M., \& Morales, M.L. (2011). Evaluation of antioxidant activity and total phenols index in persimmon vinegars produced by different processes. LWT- Food Science and Technology, 44:1591-1596.

Volz, R.K., \& McGhie, T.K. (2011). Genetic variability in apple fruit polyphenol composition in Malus $\mathrm{x}$ domestica and Malus sieversii germplasm grown in New Zealand. Journal of Agricultural and Food Chemistry, 59:11509-11521.

Yetiman, A. (2012). Identification of acetic acid bacteria in vinegar microflora by molecular techniques. MSc Thesis, Erciyes University, Kayseri, Türkiye (in Turkish).

Wolfe, K., Wu, X., \& Liu, R.H. (2003). Antioxidant activity of apple peels. Journal of Agricultural and Food Chemistry, 51:609-614.

Wu, X., Beecher, G.R., Holden, J.M., Haytowitz, D.B., Gebhardt, S.E., \& Prior, R.L. (2004). Lipophilic and hydrophilic antioxidant capacities of common foods in the United States. Journal of Agricultural and Food Chemistry, 52:4026-37. 